Article

\title{
Modeling Dark Fermentation of Coffee Mucilage Wastes for Hydrogen Production: Artificial Neural Network Model vs. Fuzzy Logic Model
}

\author{
Edilson León Moreno Cárdenas ${ }^{1,+}+\mathbb{D}$, Arley David Zapata-Zapata ${ }^{2,+}$ and Daehwan Kim ${ }^{3, * \mathbb{D}}$ \\ 1 Laboratorio de Mecanización Agrícola, Departamento de Ingeniería Agrícola y de Alimentos, Universidad \\ Nacional de Colombia-Sede Medellín, Carrera 64c \# 63-120, Código Postal 050034, Colombia; \\ elmorenoc@unal.edu.co \\ 2 Universidad Nacional de Colombia-Sede Medellín-Escuela de Química-Laboratorio de Procesos \\ Biológicos-Carrera 65 \# 59A-110, Medellín, Código Postal 050034, Colombia; adzapata@unal.edu.co \\ 3 Department of Biology, Hood College, 401 Rosemont Avenue, Frederick, MD 21701, USA \\ * Correspondence: kimd@hood.edu; Tel.: +1-765-637-8603 \\ + Authors contributed equally to the study.
}

Received: 22 February 2020; Accepted: 31 March 2020; Published: 2 April 2020

\begin{abstract}
This study presents the analysis and estimation of the hydrogen production from coffee mucilage mixed with organic wastes by dark anaerobic fermentation in a co-digestion system using an artificial neural network and fuzzy logic model. Different ratios of organic wastes (vegetal and fruit garbage) were added and combined with coffee mucilage, which led to an increase of the total hydrogen yield by providing proper sources of carbon, nitrogen, mineral, and other nutrients. A two-level factorial experiment was designed and conducted with independent variables of mucilage/organic wastes ratio, chemical oxygen demand (COD), acidification time, $\mathrm{pH}$, and temperature in a 20- $\mathrm{L}$ bioreactor in order to demonstrate the predictive capability of two analytical modeling approaches. An artificial neural network configuration of three layers with 5-10-1 neurons was developed. The trapezoidal fuzzy functions and an inference system in the IF-THEN format were applied for the fuzzy logic model. The quality fit between experimental hydrogen productions and analytical predictions exhibited a predictive performance on the accumulative hydrogen yield with the correlation coefficient $\left(R^{2}\right)$ for the artificial neural network $(>0.7866)$ and fuzzy logic model $(>0.8485)$, respectively. Further tests of anaerobic dark fermentation with predefined factors at given experimental conditions showed that fuzzy logic model predictions had a higher quality of fit $\left(R^{2}>0.9508\right)$ than those from the artificial neural network model $\left(R^{2}>0.8369\right)$. The findings of this study confirm that coffee mucilage is a potential resource as the renewable energy carrier, and the fuzzy-logic-based model is able to predict hydrogen production with a satisfactory correlation coefficient, which is more sensitive than the predictive capacity of the artificial neural network model.
\end{abstract}

Keywords: biohydrogen; coffee mucilage; organic waste; dark fermentation; modeling

\section{Introduction}

Fossil resources, including petroleum, coal, and natural gas, have been utilized as crucial energy sources for the development of worldwide industry, technology, and investment; they satisfy approximately $80 \%$ of the global energy demand and supply [1-5]. Rapid depletion of limited fossil fuels, environmental contamination, greenhouse gas emissions, and climate change issues are questionable in the availability of the fossil fuel-dependent energy system in the long term $[2,6,7]$. There are diverse alternatives to sustainable energy, such as wind, solar, nuclear, hydroelectric, and second-generation fuels from lignocellulosic biomass. Hydrogen gas has received scientific attention and thought 
as a promising future energy source because of its ability to be widely used for chemical reactant, petro-chemical reforming, diesel refinery, and to synthesize valuable chemicals [8-10]. It is well known that hydrogen is unrestricted in controversial issues of greenhouse gas and environmental population, and it provides a higher energy ( $>2.5$ times) than other combustion energies, such as hydrocarbon [11,12]. However, practical hydrogen production is not generalized, and the physico-chemical approaches for hydrogen achievements still depend on fossil resources (methane, crude oil, and coal) due to the problems associated with the cost efficiency and technical capability $[1,13]$. Biological technology or biochemical conversion is a bio-friendly attractive approach to decompose/convert water wastes and undesirable organic molecules into renewable energy and value-added molecules, i.e., hydrogen, acetic acid, butyric acid, and using microorganisms. Among the different types of biological processes, the bio-photolysis and photo-fermentation processes are able to produce relatively more hydrogen molecules than those from other methods without light [13]. In spite of the lower yield, anaerobic dark fermentation is more attentive to hydrogen production because a wide range of organic wastes and inexpensive renewable feedstock can be utilized for energy carriers with a higher production rate, lower energy supply, and appropriate yield [14-17]. For example, previous studies highlighted that the decomposition of domestic wastewater and wastepaper could produce hydrogen in anaerobic batch fermentation that results in $0.01 \mathrm{~L} \mathrm{H}_{2} / \mathrm{L}$ substrate and $0.29 \mathrm{~mol} \mathrm{H}_{2} / \mathrm{mol}$ hexose yield, respectively [18].

One primary difficulty in the practical coffee industry is the generation of unnecessary residues, such as outer skin, silver-skin, pulp, parchment, and mucilage, which are usually removed during the wet/dry coffee process. While a part of the coffee bean (endo-sperm) in the whole coffee fruit is used solely for the brewed beverage, other components are not employed but are discarded, accounting for over $50 \%$ of the initial coffee weight $[19,20]$. Braham, J.E. [21] reported that $61.1 \%(w / w)$ of the coffee components (skin, pulp, parchment, mucilage, and soluble) were disused during the wet separation and thrown out after coffee processing. A large quantity of coffee wastes is generated, an estimated approximately 15 million dry tons per year worldwide, which causes environmental issues, pollution hazards, and toxic chemical problems $[13,20,22]$. Some studies have introduced waste residues re-used in animal feed [23,24], $\alpha$-amylase [25], ethanol [19,20], and bio-sorbents for the treatment of aqueous solutions $[26,27]$. Nevertheless, the economical points, technical methods, and the high amount of undesirable components (phenols, lignin, and caffeine) in the materials hinder the practical use of coffee waste residues for further utilization [28,29].

Among different types of coffee wastes, coffee mucilage has been regarded as an alternative source for bioenergy, food, and the biochemical flat-form process due to its abundance in sugars and carbohydrates, a small portion of protein, and pectin as well as some inorganic or minerals. Orrego et al. $[19,20]$ concluded that the pentose/hexose sugars (mainly glucose and galactose) in coffee mucilage wastes are directly fermented into ethanol without pretreatment and additional supplements. More recently, our research study elucidated that anaerobic dark fermentation of coffee mucilage combined with organic wastes (whole market garbage) was capable of producing hydrogen $(0.248 \mathrm{~mol}$ $\mathrm{H}_{2}$ /mole hexose) [13].

Mathematical modeling is one of the crucial steps in food processing, biochemical reaction, bioprocess engineering, biological conversion, and scale-up processes to enhance the capability to design and manage a total process, and to predict the final product yield at low cost. In the case of anaerobic fermentative digestion, it is influenced by several critical factors, including $\mathrm{pH}$, pressure, temperature, chemical oxygen demand, reaction time, nutrition component, culture type, reactor type, and mixing conditions, which affect the microbial interaction, growth, and metabolic activity, and determine the final yield of desirable molecules, i.e., hydrogen, methanol, and butanol. Artificial neural networks (ANNs) are similar to humans' neurons in the brain, which are interconnected with an input, hidden, and outer layer in the network system [30]. It is a significant modeling approach in order to design non-linear multivariable bioprocesses and to forecast output in either not established appropriately or excessively complex processes [31]. ANN modeling provides not only the reciprocal interaction of various parameters but also the intricate associations between input and output 
factors $[10,32,33]$. The neurological function, the most advantageous tool in the ANN, is able to train with input/output variables, calculate the weight and coefficient factors, and determine the optimal conditions with the lowest differences between the practical data and model-designed output $[8,30]$. The fuzzy-logic-based approach has also received attention from many researchers and has been applied in various fields of ecosystem, environmental science, and energy evaluation and prediction of anaerobic digestive processes [34-37]. Unlike the ANN, the fuzzy-logic-based model is applied for the predictive capacity without accurate knowledge of the process system and the interactions of the parameters [38]. Since a general fuzzy system converts numerical variables of the input and output into specified-level terms (high and low), the modeling of the anaerobic fermentative process is achievable for the prediction/development of the cumulative hydrogen yield under various types of substrate and interactions of the bacterial population [13,39-41]. It is obvious that there is little to no literature for anaerobic fermentative hydrogen production from coffee mucilage combined with organic waste and its analytical modeling method. The current manuscript addresses the prediction of hydrogen production and yield in the batch system, varying the parameters of mucilage/organic waste ratio, $\mathrm{pH}$, acidification time, chemical oxygen demand, and temperature. Two-level factorial experiments were tested, and their hydrogen profiles were modeled with the ANN and fuzzy-logic-based approaches. Furthermore, the prediction of the two models was tested with more anaerobic digestive fermentations under similar conditions, and those actual data were compared to the modeled data.

\section{Materials and Methods}

\subsection{Raw Materials}

Coffee mucilage wastes (Castillo variety coffee with a coffee demucilager machine) were provided from the Casa de Sabaneta farm (Sabaneta, Colombia), situated $1551 \mathrm{~m}$ above sea level with an average temperature of $23^{\circ} \mathrm{C}$. The fruit-vegetable organic wastes (crisp lettuce, Tommy Atkins mango, Valencia orange, guava and papaya) were taken from the Central Mayorista de Antioquia (Antioquia's Wholesale Market, Medellín, Colombia). The raw materials were not sterilized and stored at $4{ }^{\circ} \mathrm{C}$ prior to use. All other reagent and chemicals in the current study were purchased from Sigma Aldrich (St. Louis, MO, USA).

\subsection{Experimental Design and Data Collection}

In order to analyze the anaerobic fermentative performance, two-level half-factorial experiments were designed through the Minitab 16 software program (Minitab 16, Minitab Inc., State College, PA, USA), following our previous study [13]. The resulting 26 sets were performed in a 20-L bioreactor with an actual working volume of $13 \mathrm{~L}$. Raw coffee mucilage samples do not require any supplements, such as carbon/nitrogen nutrients and initial microbial culture, for transforming fermentable sugars in the substrate to hydrogen since there are appropriate nutrient sources, minerals, and microorganisms in the samples $[13,19,20]$. Our earlier work found that 7 species were isolated after anaerobic dark fermentation, and 4 species (Micrococcus luteus, Kocuria kristinae, Streptococcus uberis, and Brevibacillus laterosporus) were relatively highly involved and participated in hydrogen production. Furthermore, increased hydrogen yield was observed when co-cultivation (bacterial consortium) was applied with K. kristinae and S. uberis, suggesting that the bacterial population could change the metabolic pathways and/or biochemical/molecular interactions that lead to efficient dark fermentation [13]. Briefly, a two-level factorial experimental test was designed with three different ratios $(\mathrm{w} / \mathrm{w})$ of coffee mucilage and organic wastes mixture (8:2, 5:5, and 2:8) were prepared, and additional control runs with only coffee mucilage or organic wastes were added [13]. Each anaerobic digestion was carried out with the independent variables of the substrate ratios $(\%)$, temperature $\left(30-40{ }^{\circ} \mathrm{C}\right)$, chemical oxygen demand (COD) (20-60 g oxygen/L), acidification time (24-72 h), and $\mathrm{pH}$ (5.0-6.5). The initial $\mathrm{pH}$ was regulated by adding agricultural lime (95\% calcium carbonate $\left(\mathrm{CaCO}_{3}\right), 2 \%$ humidity, and $54 \%$ soluble calcium oxide $(\mathrm{CaO}))$. Determination of COD [42,43], operation of the bioreactor, and biogas collection followed our 
previous work [13]. The detailed experimental design and its hydrogen profiles of maximum hydrogen (\%), daily hydrogen production ( $\mathrm{L} \mathrm{H}_{2}$ /day), and cumulative hydrogen $\left(\mathrm{L} \mathrm{H}_{2}\right)$ are summarized in Table 1.

Table 1. Experimental data used for the ANN and fuzzy logic model. Each anaerobic fermentation was performed in duplicate under given experimental conditions. The hydrogen production was collected. Each data was statistically analyzed with $95 \%$ significant differences.

\begin{tabular}{|c|c|c|c|c|c|c|c|c|c|c|}
\hline Run & Ratio $^{1}$ & $\begin{array}{c}\mathrm{COD} \\
\left(\mathrm{g} \mathrm{O}_{2} / \mathrm{L}\right)\end{array}$ & $\begin{array}{l}\text { Acidi. } \\
2 \\
\text { (days) }\end{array}$ & $\mathrm{pH}$ & $\begin{array}{l}\text { Temp. } \\
\left({ }^{\circ} \mathrm{C}\right)\end{array}$ & $\begin{array}{c}\text { Daily } \\
\mathrm{H}_{2}\left(\mathrm{LH}_{2} / \text { day }\right)\end{array}$ & $\begin{array}{c}\% \text { content } \\
\left(\% \mathrm{H}_{2}\right)\end{array}$ & $\begin{array}{l}\text { Accumul. } \\
\quad\left(\mathrm{LH}_{2}\right)\end{array}$ & $\begin{array}{c}\text { Yield } \\
\left(\mathrm{L} \mathrm{H}_{2} / \mathrm{L}\right)\end{array}$ & $\begin{array}{c}\text { Yield } \\
\text { (mol } \mathrm{H}_{2} / \mathrm{mol} \\
\text { Hexose) }\end{array}$ \\
\hline 1 & 10:0 & 40 & 2 & 6.0 & 35 & 0.00 & 0.00 & 0.00 & 0.00 & 0.00 \\
\hline 3 & $8: 2$ & 20 & 3 & 5.0 & 40 & 0.00 & 0.00 & 0.00 & 0.00 & 0.00 \\
\hline 4 & $8: 2$ & 60 & 1 & 5.0 & 40 & 0.00 & 0.00 & 0.00 & 0.00 & 0.00 \\
\hline 5 & $8: 2$ & 20 & 1 & 5.5 & 30 & 0.00 & 0.00 & 0.00 & 0.00 & 0.00 \\
\hline 6 & $8: 2$ & 60 & 3 & 6.0 & 40 & 0.00 & 0.00 & 0.00 & 0.00 & 0.00 \\
\hline 9 & $2: 8$ & 20 & 3 & 5.5 & 30 & 0.00 & 0.00 & 0.00 & 0.00 & 0.00 \\
\hline 10 & $2: 8$ & 60 & 3 & 5.5 & 40 & 0.00 & 0.00 & 0.00 & 0.00 & 0.00 \\
\hline 11 & $2: 8$ & 60 & 1 & 5.5 & 30 & 0.00 & 0.00 & 0.00 & 0.00 & 0.00 \\
\hline 12 & $2: 8$ & 20 & 1 & 6.0 & 30 & 1.88 & 20.87 & 1.88 & 0.35 & 0.12 \\
\hline 13 & $2: 8$ & 20 & 3 & 6.5 & 40 & 0.00 & 0.00 & 0.00 & 0.00 & 0.00 \\
\hline 14 & $0: 10$ & 40 & 2 & 6.0 & 35 & 0.43 & 14.40 & 0.43 & 0.08 & 0.02 \\
\hline 20 & $5: 5$ & 40 & 2 & 6.0 & 35 & 7.83 & 31.08 & 11.37 & 0,80 & 0.64 \\
\hline 21 & $8: 2$ & 20 & 1 & 6.0 & 40 & 0.00 & 0.00 & 0.00 & 0.00 & 0.00 \\
\hline 22 & $8: 2$ & 60 & 1 & 6.5 & 30 & 13.32 & 35.85 & 25.94 & 1.21 & 1.65 \\
\hline 23 & $8: 2$ & 20 & 3 & 6.5 & 30 & 2.27 & 32.47 & 3.36 & 0.20 & 0.38 \\
\hline 24 & $2: 8$ & 60 & 3 & 6.5 & 30 & 5.60 & 40.00 & 10.15 & 0.63 & 0.39 \\
\hline 25 & $5: 5$ & 80 & 2 & 6.0 & 35 & 5.90 & 24.70 & 8.88 & 0.49 & 0.29 \\
\hline 26 & $5: 5$ & 40 & 0 & 6.0 & 35 & 0.00 & 0.00 & 0.00 & 0.00 & 0.00 \\
\hline
\end{tabular}

Hydrogen gas in each test was collected in gas sampling Tedlar bags (Restek, LA, CA, USA) at interval times and determined with gas chromatography (3000 MicroGC system, Agilent, San Jose, CA, USA) as described in our previous study [13]. The gas chromatography was equipped with a molecular sieve column $5 \mathrm{~A}(10 \mathrm{~mm} \times 0.32 \mathrm{~mm})$ connected to a thermal conductivity detector (TCD). Argon gas was used as the carrier gas at a $0.9 \mathrm{~mL} / \mathrm{min}$ flow rate; the injector, column, and detector temperatures were kept constant at 60,80 , and $300^{\circ} \mathrm{C}$, respectively. A gas meter ( $\mathrm{G} 2.5$ volumetric, Metrex, Popayan, Cauca, Colombia) was used, which operated with a precision of $0.04 \mathrm{~m}^{3} / \mathrm{h}$, and a 40 $\mathrm{kPa}$ maximum working pressure. Statistical analysis was performed with the $\mathrm{t}$-test using the Minitab 16 program for daily hydrogen production, hydrogen content, and accumulation of hydrogen, with a 95\% significant difference.

\subsection{Analytical Modeling Approach—Artificial Neural Network (ANN)}

In order to develop the hydrogen yield prediction model in anaerobic fermentative digestion, the ANN approach employed a multilayer perceptron-type neural network [44,45]. The backpropagation algorithm was employed for training and propagation of the error, which is the widely used training algorithm in the ANN. The main advantage of this algorithm is the ability to calculate the difference/error between the output from the neural network and the actual output and back propagate them through the designed system. The algorithm is able to adjust the weights in each independent variable (input and hidden layers); the successfully repeated procedure can minimize the errors between the experimental data and model-calculated prediction $[8,30,46]$. The five input factors chosen in the current work were: i) Substrate ratios $\left(\mathrm{x}_{1}\right)$, ii) acidification time $\left(\mathrm{x}_{2}\right)$, iii) chemical oxygen demand $\left(\mathrm{x}_{3}\right)$, iv) $\mathrm{pH}\left(\mathrm{x}_{4}\right)$, and $\left.\mathrm{v}\right)$ temperature $\left(\mathrm{x}_{5}\right)$. The interactions between the independent variables on hydrogen production were considered in a hidden layer of the neural network; one dependent variable (hydrogen production) was set up in the output layer (Y1). The training was supervised (with a 
pattern), which was the experimental data obtained from each input variable. The initial weights $(\mathrm{w})$ for the connections between the layers were assigned randomly with the nn-tool option in the Matlab R2012a. The designed artificial network model is presented in Figure 1.

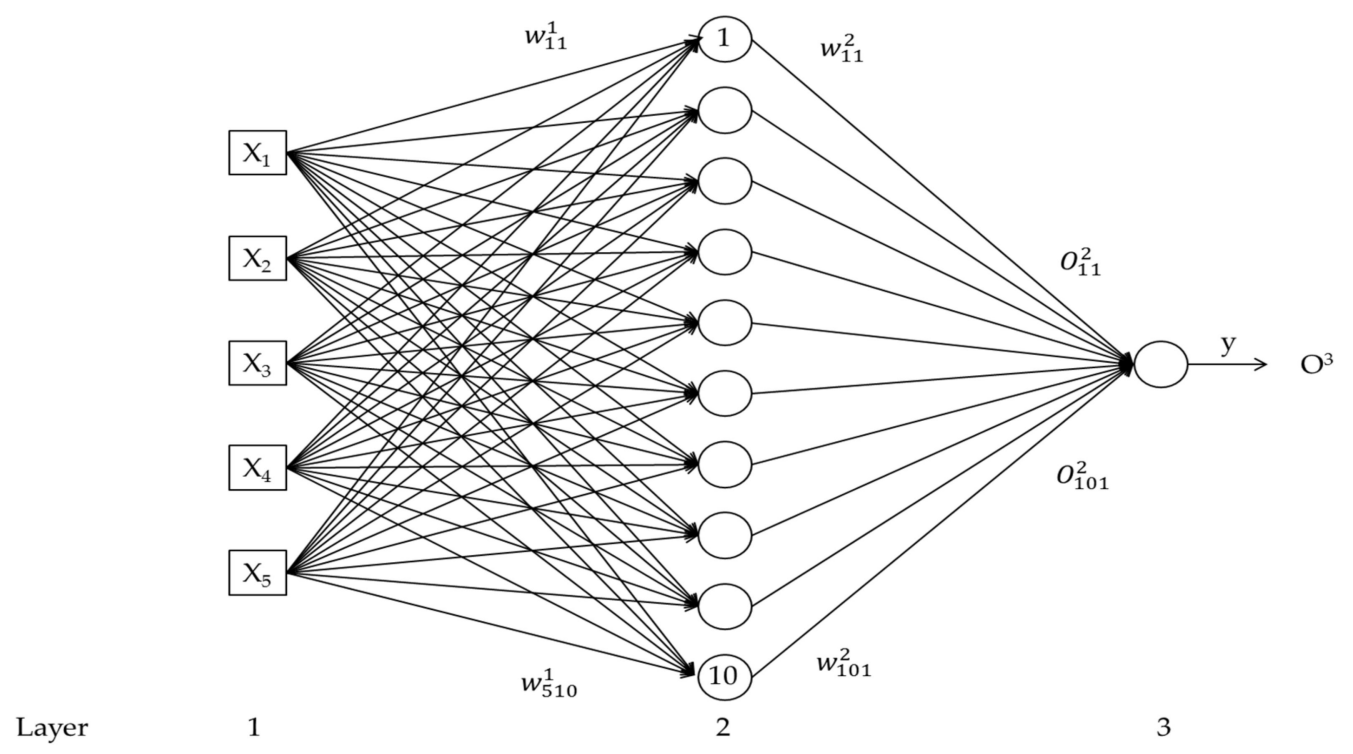

Figure 1. The neural network used in the modeling. Layer 1 includes the five input factors of i) substrate ratios $\left(\mathrm{x}_{1}\right)$, ii) acidification time $\left(\mathrm{x}_{2}\right)$, iii) chemical oxygen demand $\left.\left(\mathrm{x}_{3}\right), \mathrm{iv}\right) \mathrm{pH}\left(\mathrm{x}_{4}\right)$, and $\left.\mathrm{v}\right)$ temperature $\left(\mathrm{x}_{5}\right)$; layer 2 includes 10 neurons; and layer 3 includes the output data of hydrogen production.

To obtain the global output $\left(O^{3}\right.$, Equation (1)), the hidden layer and output layer used a sigmoid function and a linear function, respectively. The generalized form of the network output was investigated using Matlab platform R2012 syntax (MathWorks, Inc., Natick, MA, USA) as below (Equations (1) and (2)):

$$
\begin{gathered}
O^{3}=\sum_{k=1}^{m}\left(w_{k, y}^{2} * \frac{1}{\left.1+e^{-\left(\sum_{i=1}^{n} w_{i, k}^{1} * x_{i}-t\right)}\right)}\right) \\
y_{n}\left(x_{n}\right)=\text { Pureline }\left(L W^{(2,1)} * \operatorname{logsig}\left(\operatorname{IW} W^{(1,1)} * x_{n}\right)\right),
\end{gathered}
$$

where $w_{i, k}^{1}$ : The weight of the connection between the input variable $i$ in layer 1 and the neuron $k$ in layer 2; $w_{k, y}^{2}$ : The weight between the output of neuron $k$ and the output neuron in layer $3(y) ; n$ : The number of inputs in layer 1 (equal to 5); $m$ : The number of neurons in the hidden layer (10); $t$ : The learning rate (taken as zero); $L W^{(2,1)}$ : The weight vector of layer two $(Y x K$, with $Y$ number of outputs and $K$ number of neurons); and $I W^{(1,1)}$ : The weight matrix of layer one (KxX, with $K$ number of neurons and $X$ number of inputs).

The error in the network output (E, Equation (3)) was calculated as the difference between the experimental values in the response for a combination of the inputs and the predicted network output $\left(O^{3}\right)$. This error was distributed among the outputs of the previous layer, with which the error in layer two was determined $\left(E_{k}^{2}\right.$ Equation (4)). Once the error was distributed, the connection weights between elements were updated using Equation (5):

$$
\begin{gathered}
E=\text { pattern }-O^{3}, \\
E_{k}^{2}=O_{k}^{2}\left(1-O_{k}^{2}\right) *\left(w_{k, y}^{2} * E\right), \\
w_{s t}^{p}(\text { current })=w_{s t}^{p}(\text { previous })+\alpha * E_{t}^{(p+1)} * x_{s t},
\end{gathered}
$$


where $O_{k}^{2}$ : The output value for the $\mathrm{k}$ neuron in layer $2 ; w_{k, y}^{2}$ : The weight between the output of neuron $\mathrm{k}$ in layer 2 and the output neuron in layer $3 ; E_{k}^{2}$ : The output error of the $\mathrm{k}$ neuron in layer 2; $w_{s t}^{p}$ (current): The updated or recalculated weight of the connection between the $s^{\text {th }}$ neuron of the $p^{\text {th }}$ layer and the $t^{\text {th }}$ neuron of the $(p+1)^{\text {th }}$ layer; $w_{s t}^{p}$ (previous): The weight of the connection between the previous neurons without updating; $x_{s t}$ : The input of the $s^{\text {th }}$ neuron into the $t^{\text {th }}$ neuron; and $\alpha$ : The learning constant (taken as 0.3) [44].

For the training and testing of the network, the 26 experimental data were randomly distributed into two groups, one set of 18 data to training and the other 8 data to test the network. The training consisted in passes through the network of the values of the input variables for each of the 18 trials in a sequential way (values of substrate ratio, acidification time, chemical oxygen demand, $\mathrm{pH}$, and temperature), and their output was obtained from the network. In each case, the outputs of the hidden layer neurons, network error, distribution of the error backwards, and the updated weights were obtained. This procedure was developed in an iterative way until the error reached a value of less than or equal to 0.002 , defined as the maximum value accepted. The input variables were normalized (values between 0 and 1 ) before the training and testing of the network, and then the outputs were decoded into values in their original domain.

\subsection{Models with Fuzzy Logic}

In order to develop the fuzzy-logic-based model, five input variables (substrate ratio, acidification, chemical oxygen demand, $\mathrm{pH}$, and temperature) were used, and the following output data from the test was corresponded to the dependent variables. Numerical input and output data were converted into a form of linguistic levels (very low, low, medium, high, and very high), using trapezoidal membership functions (Figure 2). The fuzzification process, including inference operators, minimization, and products, is capable of providing an understanding of the variables and membership functions from multiple-input data [47-49].

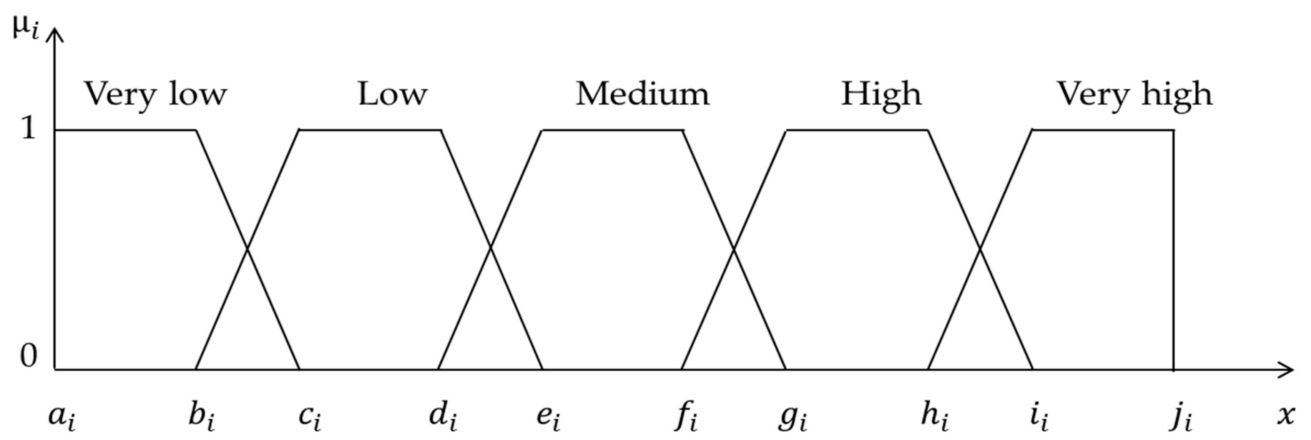

Figure 2. Representation of the variables through five fuzzy sets and their membership functions, where $\mu_{i}$, corresponds to the membership function for fuzzy sets very low, low, medium, high, and very high; $a_{i}, b_{i}, c_{i}, d_{i}, e_{i}, f_{i}, g_{i}, h_{i}, i_{i}$, and $j_{i}$ are the vertices of the fuzzy sets; and $x$ is the value of each variable (substrate ratio, acidification, chemical oxygen demand, $\mathrm{pH}$, and temperature), whose domain was defined according to the database. In the response variables, the domain was defined according to the results achieved during the tests.

The fuzzy inference system was conducted through Mandani with fuzzy inference rules based on the antecedent-consequent format given by linguistic expressions of the IF-THEN form. The AND operator was utilized to evaluate the rules (minimum method or intersection of two fuzzy sets (Equation (6)), while the aggregation was calculated by the OR operator (maximum method or union of two fuzzy sets (Equation (7)). The transformed fuzzy outputs to values in the original domain of the independent factors were completed with the centroid method described in the earlier study [38]:

$$
\mu_{A \cap B}(x)=\min \left[\mu_{A}(x), \mu_{B}(x)\right]=\wedge\left[\mu_{A}(x), \mu_{B}(x)\right],
$$




$$
\mu_{A \cup B}(x)=\max \left[\mu_{A}(x), \mu_{B}(x)\right]=\vee\left[\mu_{A}(x), \mu_{B}(x)\right],
$$

where $\mathrm{A}$ and $\mathrm{B}$ are fuzzy sets in $\mathrm{X}$ with a group of pairs such that:

$A=\left\{\left(x, \mu_{A(x)}\right) / x \in X\right\}$ and $B=\left\{\left(x, \mu_{B(x)}\right) / x \in X\right\} ;$ and $\mu_{A(x)}$ y $\mu_{B(x)}$ are membership functions for the fuzzy sets $A$ and $B$, respectively, with their domain for the $x$ variable.

\section{Results and Discussion}

\section{Implementation of the Artificial Neural Network and Fuzzy Logic Models}

Although the main aim for the comprehensive concept in the study was the production of hydrogen gas, this paper concentrated on modeling and comparing two model approaches, following on from our previous work [13], to estimate its predictability. Briefly, the carbohydrates and sugars in coffee mucilage were metabolized via the Emnden-Meyerhof (glycolytic pathway) process, which is able to produce hydrogen molecules by accepting/donating protons between adenine dinucleotide (NAD+) and nicotinamide adenine dinucleotide (NADH). The highest hydrogen yield (25.94 L equivalent to $1.21 \mathrm{~L} \mathrm{H}_{2} / \mathrm{L}$ substrate) was obtained in the presence of the blended substrate (8 mucilage: 2 organic wastes) at $30^{\circ} \mathrm{C}$, acidification time of one day, $\mathrm{pH} 6.5$, and chemical oxygen demand of $60 \mathrm{~g} \mathrm{O}_{2} / \mathrm{L}$ while less to no hydrogen production was observed in the other tests with different substrate ratios [13]. This anaerobic digestion does not require any additional carbon/nitrogen sources, light, and initial microorganism for fermentation performance because the raw materials already have the resources for dark fermentation $[13,19,20]$.

The artificial neural network model (ANN) architecture (5-10-1) was built for both acclimatization of the model-calculated prediction and the experimental phase (Figure 1). We aimed to reach an error less than or equal to 0.002 that was available at a hidden layer with 10 neurons. Since the increase in neurons at the hidden layer could result in high values of the error and unacceptable data [50], the training algorithm in the neuron system was fixed with 10 neurons. The data from the cumulative hydrogen production variable were passed through the network to obtain the error; its training continued until 175 iterations, resulting in a coefficient of determination of 0.7866 (Figure 3A). The final weight matrix was determined between the inputs and the 10 neurons of the hidden layer $\left(I W^{(1,1)}\right)$, and the weight vector between the 10 neurons of the hidden layer and the output $\left(\operatorname{LW}{ }^{(2,1)}\right)$. The matrix connections $\left(I W^{(1,1)}\right)$ and those of the vector $\left(L W^{(2,1)}\right)$ were determined with the lowest errors. The weights matrix and the weight vector (accumulative hydrogen production) are tabulated in Table 2.
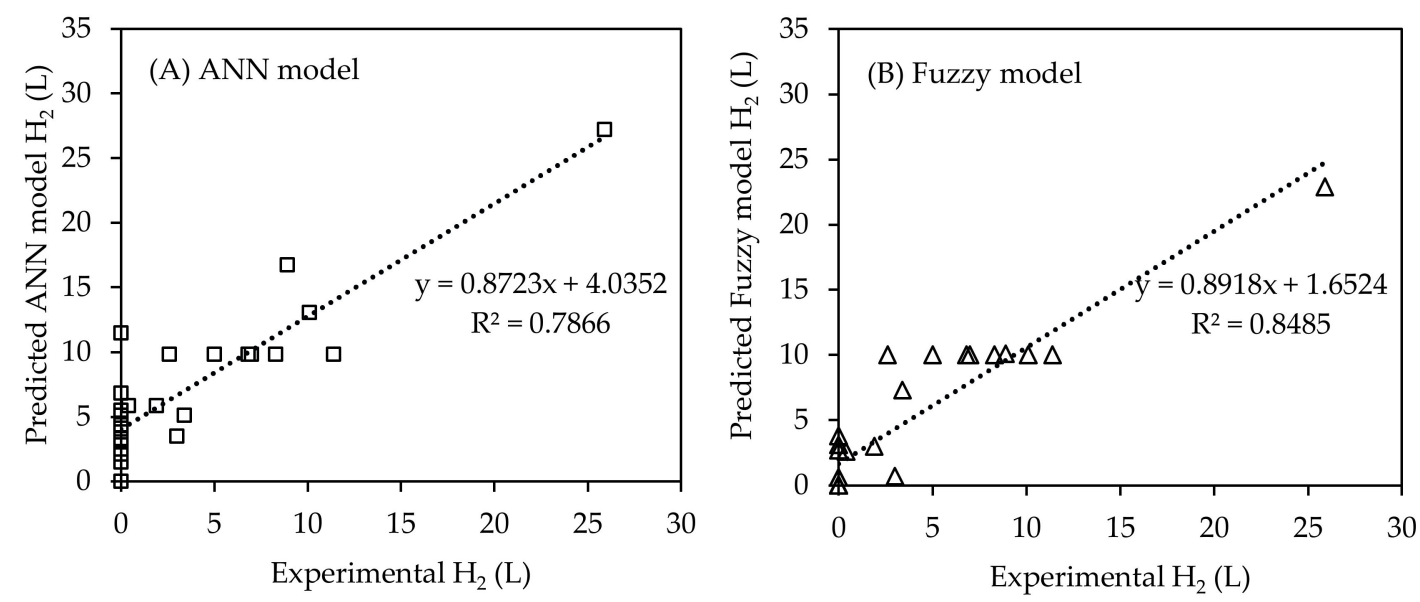

Figure 3. Comparisons between the experimental and predicted data used in (A) tthe ANN model and (B) fuzzy model. 
Table 2. Artificial neural network model training parameters for the final weights' matrix and vector of the accumulative hydrogen production. The positive (+) and negative (-) sign represent an increase or decrease in the connection between neurons, respectively.

\begin{tabular}{ccccccc}
\hline \multicolumn{7}{c}{ The Cumulative Hydrogen Production } \\
\hline \multirow{2}{*}{ Neuron } & \multicolumn{3}{c}{ Layer 1 Weight Matrix } & Layer 2 \\
& \multicolumn{7}{c}{$\begin{array}{c}\text { Substrate } \\
\text { Ratio }\end{array}$} & COD & Acidification & pH & Temperature & $\begin{array}{c}\text { Weight } \\
\text { Vector }\end{array}$ \\
\cline { 2 - 6 } & -1.022 & -1.392 & -0.428 & -0.541 & -1.648 & -1.032 \\
2 & 1.501 & 0.970 & -0.502 & -0.034 & -0.898 & -0.239 \\
3 & 0.606 & 1.882 & 1.101 & -0.964 & -1.301 & 1.089 \\
4 & -0.954 & 1.287 & -2.428 & 0.531 & -0.511 & 1.294 \\
5 & -0.440 & -1.106 & -1.574 & 0.673 & -0.956 & 0.106 \\
6 & -1.162 & 0.275 & -0.963 & -0.298 & 1.365 & -0.378 \\
7 & 0.549 & -0.100 & -0.631 & -0.657 & 1.832 & -0.642 \\
8 & -1.824 & 1.298 & 0.706 & -1.265 & -1.910 & -1.477 \\
9 & -1.357 & 0.631 & 1.314 & 1.413 & 0.779 & 0.457 \\
10 & -0.039 & 1.016 & -1.547 & -1.090 & -0.765 & -0.121 \\
\hline
\end{tabular}

Similar to the neural network model, the fuzzy logic-based model was applied to forecast hydrogen gas production from the two-level half-factorial design experiments. The membership functions with five input variables developed five diffuse sets of five linguistic levels (very low, low, medium, high, and very high). The membership functions and their ranks for each input and output variables are summarized in Table 3. A total of 1595 linguistic rules in the IF-THEN format were used to develop the fuzzy logic-based model with 26 experimental data by testing with different input parameters. There are two reasoning fuzzy systems (Mamdani vs. Takagi-Sugeno type) for applying the variables from the combination of input and membership functions to estimate output [47,51]. Since Mamdani's approach is more suitable to apply fuzzy inference by interpreting the fuzzy rules than the Takagi-Sugeno method, Mamdani's fuzzy inference method was used to forecast the hydrogen production. Each input factor was defined between 0 and 100 for the substrate ratio, 0 and $83 \mathrm{~g} \mathrm{O}_{2} / \mathrm{L}$ for COD, 0 and 3 days for acidification, 30 and $40^{\circ} \mathrm{C}$ for temperature, and 0 and 6.5 for $\mathrm{pH}$, respectively. Figure 3B presents the correlation $\left(R^{2}=0.8485\right)$ between the experimental cumulative hydrogen production and those predicted generations through the fuzzy model for data pointing. Even though some experimental tests showed little to no hydrogen production, the two modeling analyses assessed and predicted the accumulative hydrogen yields. Comparing the hydrogen predictions using the two different models, the fuzzy model was more fitted, with a $>84 \%$ coefficient correlation, than those from the ANN model, with a $>77 \%$ correlation coefficient.

Table 3. Membership functions and their information for each input and output variable.

\begin{tabular}{|c|c|c|c|c|c|c|}
\hline \multirow{2}{*}{$\begin{array}{l}\text { Membership } \\
\text { Functions }\end{array}$} & \multicolumn{5}{|c|}{ Input Variable } & \multirow{2}{*}{$\begin{array}{c}\text { Output } \\
\text { Hydrogen }\left(\mathrm{LH}_{2}\right)\end{array}$} \\
\hline & $\begin{array}{c}\text { Substrate } \\
\text { Ratio }\end{array}$ & $\begin{array}{l}\mathrm{COD}(\mathrm{g} \\
\left.\mathrm{O}_{2} / \mathrm{L}\right)\end{array}$ & $\begin{array}{l}\text { Acidification } \\
\text { (Days) }\end{array}$ & $\mathrm{pH}$ & $\begin{array}{c}\text { Temperature } \\
\left({ }^{\circ} \mathrm{C}\right)\end{array}$ & \\
\hline Very Low & {$\left[\begin{array}{llll}0 & 0 & 19 & 25\end{array}\right]$} & {$\left[\begin{array}{llll}0 & 0 & 0 & 0\end{array}\right]$} & {$\left[\begin{array}{llll}0 & 0 & 0 & 0\end{array}\right]$} & {$\left[\begin{array}{llll}0 & 0 & 0 & 0\end{array}\right]$} & [30 3031 32] & {$\left[\begin{array}{lllll}0 & 0 & 0.6 & 1.7\end{array}\right]$} \\
\hline Low & 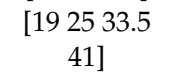 & {$\left[\begin{array}{llll}0 & 0 & 15 & 25\end{array}\right]$} & {$\left[\begin{array}{llll}0 & 0 & 0.3 & 0.7\end{array}\right]$} & 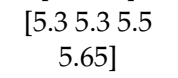 & [31 3233 34] & {$\left[\begin{array}{llll}0.6 & 1.7 & 5.5 & 7.5]\end{array}\right.$} \\
\hline Medium & $\begin{array}{c}\text { [33.5 } 4150 \\
59]\end{array}$ & {$\left[\begin{array}{lllll}15 & 25 & 37 & 47\end{array}\right]$} & 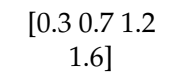 & $\begin{array}{l}\text { [5.5. } 5.655 .9 \\
6]\end{array}$ & [33 3435 36] & {$\left[\begin{array}{llll}5.5 & 7.5 & 12 & 15\end{array}\right]$} \\
\hline High & [50 5969 78] & 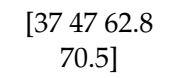 & $\begin{array}{c}{\left[\begin{array}{ll}1.2 & 1.6 \\
2.5 & 2.1 \\
2.5\end{array}\right]}\end{array}$ & 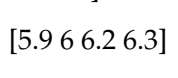 & [35 $\left.36 \begin{array}{lll}38 & 39\end{array}\right]$ & {$\left[\begin{array}{llll}12 & 15 & 21 & 24\end{array}\right]$} \\
\hline Very High & $\begin{array}{c}{\left[\begin{array}{c}6977100 \\
100]\end{array}\right.}\end{array}$ & $\begin{array}{l}{[62.870 .5} \\
83.383 .3]\end{array}$ & {$\left[\begin{array}{llll}2.1 & 2.5 & 3 & 3\end{array}\right]$} & 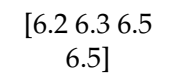 & [38 394040 ] & [21 2430 30] \\
\hline
\end{tabular}

In order to acquire an accurate prediction response with a higher probability worth (coefficient correlation) in both the ANN and fuzzy models, the poor bi-lateral parameters, including substrate*COD 
and acidification ${ }^{*} \mathrm{pH}$, were excluded, and accurate architectures were simulated and created. The experimental and predicted hydrogen production by the ANN and fuzzy models are compared in Figure 4. Coefficient correlations $\left(R^{2}\right)$ of 0.8369 and 0.9508 were achieved for validation of the ANN and fuzzy models, respectively, and these results indicated that the prediction of hydrogen in this experimental design was $83.69 \%$ and $95.08 \%$, respectively. It is definite that both models accurately predicted the hydrogen production in given conditions, and the fuzzy model was better than the ANN model, as reflected by $\mathrm{R}^{2}$ of 0.8369 and 0.9508 .
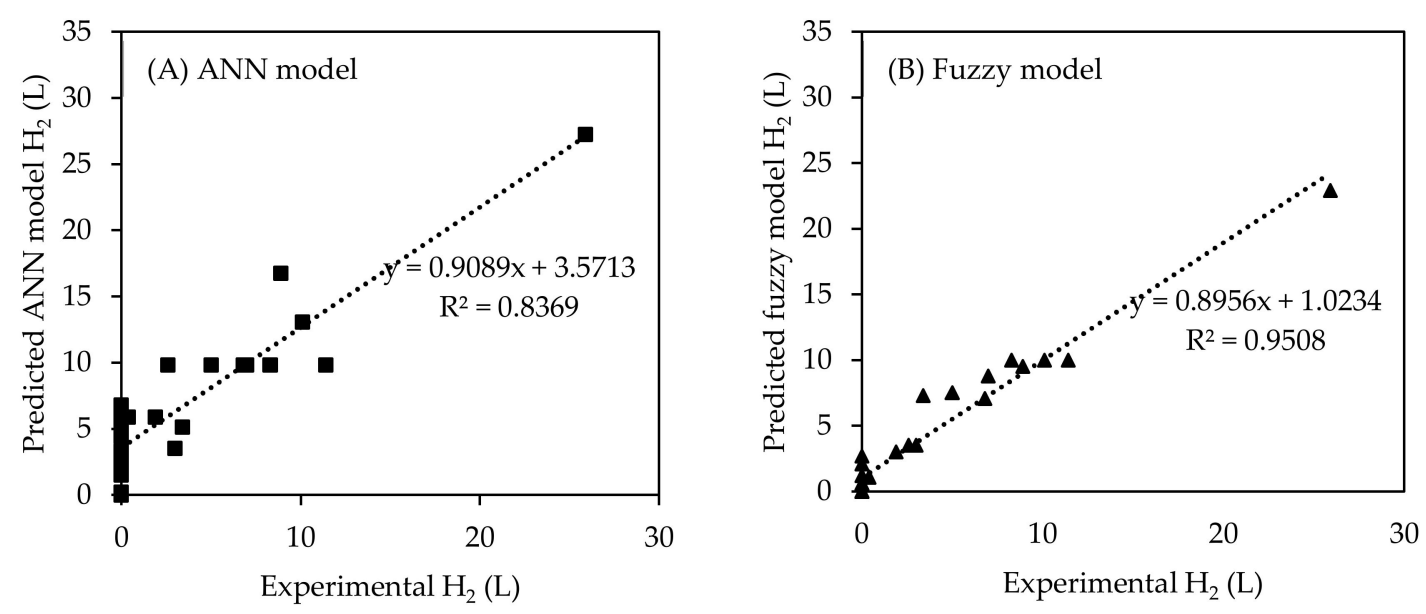

Figure 4. Correlation between the experimental and predicted training hydrogen production data used in (A) the ANN model and (B) fuzzy model.

In both models, an adequate fit was observed in the linear trends between the predicted and experimental hydrogen production. Prediction model training with connection weights in the input and hidden neurons improved the correlation efficient. The $R^{2}$ values for hydrogen production confirmed that the model was able to predict the hydrogen generation in a dark fermentation phase closer to the experimental results. The correlation efficient in this study is comparable with earlier research studies with the modeling on hydrogen production from other substrates that is summarized in Table 4. A similar or higher $\mathrm{R}^{2}$ value was obtained for both the ANN and fuzzy models compared with a comparative study of modeling on hydrogen production. The hydrogen production of simple sugars, such as glucose and lactose, seems to have a proper fit since mixed waste substrates have complex compositions that may dominantly contribute to cell growth, consumption of substrates, metabolic pathways, and biochemical conversion associated with hydrogen production in anaerobic fermentative conditions [13]. 
Table 4. Comparative research studies of neural network/fuzzy modeling of hydrogen production from different substrates.

\begin{tabular}{|c|c|c|c|c|c|c|}
\hline Model & Substrate & Reactor & Input & Output & $\mathbf{R}^{2}$ & Reference \\
\hline ANN/Fuzzy logic & $\begin{array}{l}\text { Coffee } \\
\text { mucilage }+ \\
\text { organic }\end{array}$ & Batch & $\begin{array}{l}\text { Substrate ratio, COD, } \\
\text { acidification, temperature, } \mathrm{pH}\end{array}$ & $\begin{array}{l}\text { Hydrogen } \\
\text { production }\end{array}$ & $0.8369 / 0.9508$ & $\begin{array}{l}\text { Current } \\
\text { work }\end{array}$ \\
\hline Neural network & Glucose & Batch & $\begin{array}{c}\text { Initial glucose concentration, } \\
\text { initial biomass concentration, } \\
\text { pH, temperature, time }\end{array}$ & $\begin{array}{l}\text { Hydrogen } \\
\text { production }\end{array}$ & 0.987 & [8] \\
\hline Neural network & Lactose & Batch & $\mathrm{ORP}^{1}, \mathrm{pH}$, dissolved $\mathrm{CO}_{2}$ & $\begin{array}{l}\text { Hydrogen } \\
\text { production }\end{array}$ & 0.955 & [52] \\
\hline Neural network & Glucose & HUASB $^{2}$ & Time, $\mathrm{COD}^{3}, \mathrm{pH}, \mathrm{VFA}^{4}$ & $\begin{array}{l}\text { Hydrogen } \\
\text { production } \\
\text { rate }\end{array}$ & 0.823 & {$[50]$} \\
\hline Fuzzy logic & Molasses & $\mathrm{UASB}^{5}$ & $\begin{array}{l}\text { OLR }^{6}, \text { TCOD removal rate } \\
\left(\mathrm{R}_{\mathrm{V}}\right)^{7} \text {, influent alkalinity, } \mathrm{pH}\end{array}$ & Biogas & 0.9847 & [38] \\
\hline Fuzzy logic & Molasses & UASB & $\begin{array}{l}\text { OLR, VCOD removal rate }\left(R_{\mathrm{V}}\right), \\
\text { influent alkalinity, } \mathrm{pH}\end{array}$ & Methane & 0.9848 & [38] \\
\hline
\end{tabular}

${ }^{1}$ ORP: Oxidation-reduction potential. ${ }^{2}$ HUASB: Hybrid up-flow anaerobic sludge blanket reactor. ${ }^{3}$ COD: Chemical oxygen demand. ${ }^{4}$ VFA: Volatile fatty acids. ${ }^{5}$ UASB: Up-flow anaerobic sludge blanket reactor. ${ }^{6}$ OLR: Organic loading rate. ${ }^{7}$ TCOD: Total chemical oxygen demand removal rate.

It is worthwhile to address that the prediction and estimation of hydrogen production from pure substrates via anaerobic fermentative performances is more accurate for a modeling study than those from mixed substrates due to potential factors that affect the hydrogen production [53,54]. However, the supplementation of essential sources (phosphorous, ferrous, nitrogen, mineral, and metals) from waste materials could positively impact the anaerobic cell growth and support hydrogen-producing metabolisms to improve the final hydrogen production. Margarida et al. [55] highlighted that the carbon/nitrogen ratio is a primary factor for anaerobic fermentative digestion, and they found that the additional nitrogen provided by organic wastes improved the hydrogen yield by increasing the $\mathrm{C} / \mathrm{N}$ ratios. Furthermore, phosphorous $(\mathrm{P})$ plays a role in adenosine triphosphate synthesis; the additional phosphorus could support the enzyme linkage and metabolic pathway for hydrogen production during anaerobic fermentation [54].

\section{Conclusions}

The hydrogen production from unutilized coffee mucilage combined with organic waste was predicted by two different approaches of ANN and fuzzy models. Anaerobic digestion was carried out with five input factors, including the substrate ratio, $\mathrm{COD}$, acidification time, $\mathrm{pH}$, and temperature, using a two-level factorial design test, and the consequent hydrogen yields were analyzed and fitted for the final hydrogen yields. This study confirmed that the use of the experimental results for bio-digestion of the waste substrate in a batch reactor with the ANN and fuzzy model was predictive, achieving an $\mathrm{R}^{2}$ value of 0.8369 and 0.9508 , respectively. The fuzzy model had a greater predictive capacity than the ANN model with the response to the interaction of independent factors: Hydrogen yield $(\mathrm{L})=-137,74-$ $0.93^{*}$ substrate ratio $-0.00124^{*} \mathrm{COD}+7.65^{*}$ acidification $+23.79^{*} \mathrm{pH}+5.88^{*}$ temperature $-0.09^{*}$ substrate ratio*acidification $+0.22^{*}$ substrate ratio* $\mathrm{pH}-0.0000988^{*} \mathrm{COD}^{*}$ acidification $+0.000258^{*} \mathrm{COD}^{*} \mathrm{pH}$ $+0.2^{*}$ acidification*temperature $-1.14^{*} \mathrm{pH}^{*}$ temperature $-0.00182^{*}$ substrate ratio*substrate ratio $1.7^{*}$ acidification*acidification. The use of coffee waste as an alternative source for energy production can be considered, suggesting a practical and efficient application for industrial strategy.

Author Contributions: E.L.M.C. and A.D.Z.-Z. primarily conceived, designed the model and performed the presented experiments at the Universidad Nacional de Colombia. D.K. at Hood College contributed to review, data analysis, and complete the manuscript with support from E.L.M.C. All authors discussed the results and commented on the manuscript. All authors have read and agreed to the published version of the manuscript.

Funding: Universidad Nacional de Colombia, grant number: 19522, 24025 and 30085. D.K. supported by the Maryland E-Nnovation Initiative Fund (MEIF) administered by the Maryland Department of Commerce. 
Acknowledgments: The authors thank the Casa de Sabaneta farm (Sabaneta, Colombia) and the Central Mayorista de Antioquia (Medellín, Colombia) for providing coffee mucilage and organic wastes, respectively. The authors also thank Donna Harrison at Hood College for the internal review and revision of the draft.

Conflicts of Interest: The authors declare no conflict of interest.

\section{References}

1. Brentner, L.B.; Jordan, P.A.; Zimmerman, J.B. Challenges in developing biohydrogen as a sustainable energy source: Implications for a research agenda. Environ. Sci. Technol. 2010, 44, 2243-2254. [CrossRef]

2. Kim, D. Physico-chemical conversion of lignocellulose: Inhibitor effects and detoxification strategies: A mini review. Molecules 2018, 23, 309. [CrossRef]

3. Ladeira Ázar, R.I.S.; Bordignon-Junior, S.E.; Laufer, C.; Specht, J.; Ferrier, D.; Kim, D. Effect of Lignin Content on Cellulolytic Saccharification of Liquid Hot Water Pretreated Sugarcane Bagasse. Molecules 2020, $25,623$. [CrossRef]

4. Kim, D.; Ximenes, E.A.; Nichols, N.N.; Cao, G.; Frazer, S.E.; Ladisch, M.R. Bioresource Technology Maleic acid treatment of biologically detoxified corn stover liquor q. Bioresour. Technol. 2016, 216, 437-445. [CrossRef]

5. Kim, D.; Ku, S. Bacillus cellulase molecular cloning, expression, and surface display on the outer membrane of Escherichia coli. Molecules 2018, 23, 503. [CrossRef]

6. Kim, D.; Orrego, D.; Ximenes, E.A.; Ladisch, M.R. Cellulose conversion of corn pericarp without pretreatment. Bioresour. Technol. 2017, 245, 511-517. [CrossRef]

7. Cao, G.; Ximenes, E.; Nichols, N.N.; Frazer, S.E.; Kim, D.; Cotta, M.A.; Ladisch, M. Bioabatement with hemicellulase supplementation to reduce enzymatic hydrolysis inhibitors. Bioresour. Technol. 2015, 190, 412-415. [CrossRef]

8. Nasr, N.; Hafez, H.; El, M.H.; Nakhla, G. Application of artificial neural networks for modeling of biohydrogen production. Int. J. Hydrogen Energy 2013, 38, 3189-3195. [CrossRef]

9. Mizuno, O.; Dinsdale, R.; Hawkes, F.R.; Hawkes, D.L.; Noike, T. Enhancement of hydrogen production from glucose by nitrogen gas sparging. Bioresour. Technol. 2000, 73, 59-65. [CrossRef]

10. Zhang, K.; Ren, N.Q.; Wang, A.J. Fermentative hydrogen production from corn stover hydrolyzate by two typical seed sludges: Effect of temperature. Int. J. Hydrogen Energy 2015, 40, 3838-3848. [CrossRef]

11. Jung, K.W.; Kim, D.H.; Shin Hang-Sik, H.S. Fermentative hydrogen production from Laminaria japonica and optimization of thermal pretreatment conditions. Bioresour. Technol. 2011, 102, 2745-2750. [CrossRef]

12. Levin, D.B.; Pitt, L.; Love, M. Biohydrogen production: Prospects and limitations to practical application. Int. J. Hydrogen Energy 2004, 29, 173-185. [CrossRef]

13. Cárdenas, E.L.M.; Zapata-Zapata, A.D.; Kim, D. Hydrogen Production from Coffee Mucilage in Dark Fermentation with Organic Wastes. Energies 2019, 12, 71. [CrossRef]

14. Gadhamshetty, V.; Arudchelvam, Y.; Nirmalakhandan, N.; Johnson, D.C. Modeling dark fermentation for biohydrogen production: ADM1-based model vs. Gompertz model. Int. J. Hydrogen Energy 2010, 35, 479-490. [CrossRef]

15. Kapdan, I.K.; Kargi, F. Bio-hydrogen production from waste materials. Enzyme Microb. Technol. 2006, 38, 569-582. [CrossRef]

16. Vardar-Schara, G.; Maeda, T.; Wood, T.K. Metabolically engineered bacteria for producing hydrogen via fermentation. Microb. Biotechnol. 2008, 1, 107-125. [CrossRef]

17. Agler, M.T.; Wrenn, B.A.; Zinder, S.H.; Angenent, L.T. Waste to bioproduct conversion with undefined mixed cultures: The carboxylate platform. Trends Biotechnol. 2011, 29, 70-78. [CrossRef]

18. Van Ginkel, S.W.; Oh, S.E.; Logan, B.E. Biohydrogen gas production from food processing and domestic wastewaters. Int. J. Hydrogen Energy 2005, 30, 1535-1542. [CrossRef]

19. Orrego, D.; Zapata-Zapata, A.D.; Kim, D. Optimization and scale-up of coffee mucilage fermentation for ethanol production. Energies 2018, 11, 786. [CrossRef]

20. Orrego, D.; Zapata-zapata, A.D.; Kim, D. Bioresource Technology Reports Ethanol production from co ff ee mucilage fermentation by S. cerevisiae immobilized in calcium-alginate beads. Bioresour. Technol. Rep. 2018, 3, 200-204. [CrossRef]

21. Braham, J.E. Coffee pulp: Composition, technology, and utilization. Int. Dev. Res. Cent. 1979, 51-54. 
22. Mussatto, S.I.; Machado, E.M.S.; Carneiro, L.M.; Teixeira, J.A. Sugars metabolism and ethanol production by different yeast strains from coffee industry wastes hydrolysates. Appl. Energy 2012, 92, 763-768. [CrossRef]

23. Brand, D.; Pandey, A.; Roussos, S.; Soccol, C.R. Biological detoxification of coffee husk by filamentous fungi using a solid state fermentation system. Enzyme Microb. Technol. 2000, 27, 127-133. [CrossRef]

24. Brand, D.; Pandey, A.; Rodriguez-Leon, J.A.; Roussos, S.; Brand, I.; Soccol, C.R. Packed bed column fermenter and kinetic modeling for upgrading the nutritional quality of coffee husk in solid-state fermentation. Biotechnol. Prog. 2001, 17, 1065-1070. [CrossRef] [PubMed]

25. Murthy, P.S.; Naidu, M.M.; Srinivas, P. Production of $\alpha$-amylase under solid-state fermentation utilizing coffee waste. J. Chem. Technol. Biotechnol. 2009, 84, 1246-1249. [CrossRef]

26. Oliveira, L.S.; Franca, A.S.; Alves, T.M.; Rocha, S.D.F. Evaluation of untreated coffee husks as potential biosorbents for treatment of dye contaminated waters. J. Hazard. Mater. 2008, 155, 507-512. [CrossRef]

27. Oliveira, W.E.; Franca, A.S.; Oliveira, L.S.; Rocha, S.D. Untreated coffee husks as biosorbents for the removal of heavy metals from aqueous solutions. J. Hazard. Mater. 2008, 152, 1073-1081. [CrossRef]

28. Khelil, O.; Choubane, S.; Cheba, B.A. Polyphenols content of spent coffee grounds subjected to physico-chemical pretreatments influences lignocellulolytic enzymes production by Bacillus sp. R2. Bioresour. Technol. 2016, 211, 769-773. [CrossRef]

29. Murthy, P.S.; Madhava Naidu, M. Sustainable management of coffee industry by-products and value addition-A review. Resour. Conserv. Recycl. 2012, 66, 45-58. [CrossRef]

30. Nagata, Y.; Chu, K.H. Optimization of a fermentation medium using neural networks and genetic algorithms. Biotechnol. Lett. 2003, 25, 1837-1842. [CrossRef]

31. Sewsynker-Sukai, Y.; Gueguim Kana, E.B. Does the volume matter in bioprocess model development? An insight into modelling and optimization of biohydrogen production. Int. J. Hydrogen Energy 2017, 42, 5780-5792. [CrossRef]

32. Nasr, N.; Elbeshbishy, E.; Hafez, H.; Nakhla, G.; El Naggar, M.H. Bio-hydrogen production from thin stillage using conventional and acclimatized anaerobic digester sludge. Int. J. Hydrogen Energy 2011, 36, 12761-12769. [CrossRef]

33. Hallenbeck, P.C.; Ghosh, D. Advances in fermentative biohydrogen production: The way forward? Trends Biotechnol. 2009, 27, 287-297. [CrossRef] [PubMed]

34. Abdallah, M.; Fernandes, L.; Warith, M.; Rendra, S. A fuzzy logic model for biogas generation in bioreactor landfills. Can. J. Civ. Eng. 2009, 36, 701-708. [CrossRef]

35. Perendeci, A.; Arslan, S.; Çelebi, S.S.; Tanyolaç, A. Prediction of effluent quality of an anaerobic treatment plant under unsteady state through ANFIS modeling with on-line input variables. Chem. Eng. J. 2008, 145, 78-85. [CrossRef]

36. Scherer, P.; Lehmann, K.; Schmidt, O.; Demirel, B. Application of a fuzzy logic control system for continuous anaerobic digestion of low buffered, acidic energy crops as mono-substrate. Biotechnol. Bioeng. 2009, 102, 736-748. [CrossRef]

37. Tay and Zhang 2000-A Fast Predicting Neural Fuzzy Model for High-Rate Anaerobic Wastewater Treatment Systems. Water Research. 2000, 11, 2849-2860.

38. Turkdogan-aydınol, F.I.; Yetilmezsoy, K. A fuzzy-logic-based model to predict biogas and methane production rates in a pilot-scale mesophilic UASB reactor treating molasses. Wastewater 2010, 182, 460-471.

39. Khanna, N.; Kotay, S.M.; Gilbert, J.J.; Das, D. Improvement of biohydrogen production by Enterobacter cloacae IIT-BT 08 under regulated pH. J. Biotechnol. 2011, 152, 9-15. [CrossRef]

40. Boni, M.R.; Sbaffoni, S.; Tuccinardi, L.; Viotti, P. Development and calibration of a model for biohydrogen production from organic waste. Waste Manag. 2013, 33, 1128-1135. [CrossRef]

41. Prakasham, R.S.; Sathish, T.; Brahmaiah, P. Imperative role of neural networks coupled genetic algorithm on optimization of biohydrogen yield. Int. J. Hydrogen Energy 2011, 36, 4332-4339. [CrossRef]

42. Hernández, M.A.; Rodríguez Susa, M.; Andres, Y. Use of coffee mucilage as a new substrate for hydrogen production in anaerobic co-digestion with swine manure. Bioresour. Technol. 2014, 168, 112-118. [CrossRef] [PubMed]

43. Moreno Cardenas, E.L.; Cano Quintero, D.J.; Elkin Alonso, C.M. Generation of Biohydrogen by Anaerobic Fermentation of Organics Wastes in Colombia. Liq. Gaseous Solid Biofuels Convers. Tech. 2013, 378-400. [CrossRef]

44. Ross, T.J.; Ross, T.J. Fuzzy Logic with Engineering Applications, 3rd ed.2010; ISBN 9780470743768. 
45. Batstone, D.J.; Keller, J. Industrial applications of the IWA anaerobic digestion model No. 1 (ADM1). Water Sci. Technol. 2003, 47, 199-206. [CrossRef] [PubMed]

46. Nath, K.; Das, D. Modeling and optimization of fermentative hydrogen production. Bioresour. Technol. 2011, 102, 8569-8581. [CrossRef] [PubMed]

47. Akkurt, S.; Tayfur, G.; Can, S. Fuzzy logic model for the prediction of cement compressive strength. Cem. Concr. Res. 2004, 34, 1429-1433. [CrossRef]

48. Sözen, A.; Kurt, M.; Akçayol, M.A.; Özalp, M. Performance prediction of a solar driven ejector-absorption cycle using fuzzy logic. Renew. Energy 2004, 29, 53-71. [CrossRef]

49. Kuşan, H.; Aytekin, O.; Özdemir, I. The use of fuzzy logic in predicting house selling price. Expert Syst. Appl. 2010, 37, 1808-1813. [CrossRef]

50. Sridevi, K.; Sivaraman, E.; Mullai, P. Bioresource Technology Back propagation neural network modelling of biodegradation and fermentative biohydrogen production using distillery wastewater in a hybrid upflow anaerobic sludge blanket reactor. Bioresour. Technol. 2014, 165, 233-240. [CrossRef]

51. Takagi, T.; Sugeno, M. Fuzzy Identification of Systems and Its Applications to Modeling and Control. IEEE Trans. Syst. Man Cybern. 1985, SMC-15, 116-132. [CrossRef]

52. Rosales-Colunga, L.M.; García, R.G.; De León Rodríguez, A. Estimation of hydrogen production in genetically modified E. coli fermentations using an artificial neural network. Int. J. Hydrogen Energy 2010, 35, 13186-13192. [CrossRef]

53. Lin, C.Y.; Lay, C.H. Carbon/nitrogen-ratio effect on fermentative hydrogen production by mixed microflora. Int. J. Hydrogen Energy 2004, 29, 41-45. [CrossRef]

54. Lin, C.Y.; Lay, C.H. Effects of carbonate and phosphate concentrations on hydrogen production using anaerobic sewage sludge microflora. Int. J. Hydrogen Energy 2004, 29, 275-281. [CrossRef]

55. Manigandan, S.; Gunasekar, P.; Devipriya, J.; Nithya, S. Determination of heat flux on dual bell nozzle by Monte carlo method. J. Chem. Pharm. Sci. 2007, 98, 69-79.

(C) 2020 by the authors. Licensee MDPI, Basel, Switzerland. This article is an open access article distributed under the terms and conditions of the Creative Commons Attribution (CC BY) license (http://creativecommons.org/licenses/by/4.0/). 